\title{
Antioxidant activity of coffee added with sword bean
}

\author{
Hun Cheon Bae, Hae Seong Kim, Eun Hye Kim, Jae-Hak Moon* \\ Department of Food Science and Technology, College of Agriculture and Life Sciences, \\ Chonnam National University, Gwangju 61186, Korea
}

\section{작두콩 첨가 커피의 항산화능 평가}

\author{
배훈천 · 김해성 · 김은혜·문제학* \\ 전남대학교 농업생명과학대학 식품공학과
}

\begin{abstract}
Coffee is one of the most popular non-alcoholic beverages worldwide and is known to exhibit various beneficial therapeutic effects. Recently, studies on blending coffee, which contains added natural sources of biologically active compounds, have been published, with the aim of enhancing the health benefits of coffee-based beverages. For example, sword bean (SB) has been reported to exert various physiological activities and roasted SB is consumed as a coffee-like drink. Thus, we herein selected SB as a blending material to enhance the health function of coffee. SB-added coffee samples were prepared by mixing SB extract with coffee extract, and the antioxidant activities of the resulting mixtures were evaluated. The total phenolics content, DPPH radical-scavenging activity, reducing power, $\mathrm{ABTS}^{+}$radical-scavenging activity, and hydroxyl radical-scavenging activity found to be directly proportional to the quantity of added SD extract. Moreover, inhibitory effects on the formation of cholesteryl ester hydroperoxides in copper ion-induced rat blood plasma oxidation were observed even upon the oral administration of only a small quantity of SD-blended coffee. It was therefore suggested that SB exhibits potential for use as a blending material for coffee beverages, whereby the intake of SB-added coffee may have more beneficial health properties in vivo compared to the intake of coffee beverages alone.
\end{abstract}

Key words : coffee, sword bean, blending coffee, total phenolics, antioxidant activities

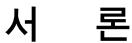

커피는 꼭두서니과(Rubiaceae)의 코페아속(Coffea)으로 분류되는 다년생 쌍떡잎식물로(Lashermes 등, 1999) 에티 오피아에서 유래한 아라비카종(Coffea arabica)과 콩고에 서 최초로 발견된 카네포라종(Coffea canephora)이 대표적 이다(Davis 등, 2006). 아라비카종은 주로 고지대에서 자라 고 병충해에 약하지만, 다당류의 함량이 높아서 맛과 향이 뛰어나며, 전 세계 커피 생산량의 약 $60 \%$ 가량을 차지하고 있다(USDA, 2017). 로부스타(Robusta)란 이름으로 익숙한
카네포라종은 병충해에 강하고, 고온 다습한 저지대에서 잘 자라지만 맛이 쓰고 강해서 대부분 인스턴트커피나 블렌딩 소재로 사용되며, 전 세계 커피 생산량의 약 $40 \%$ 정도를 차지하고 있다(Sanz 등, 2002; USDA, 2017). 보통 품질이 우수한 스페셜티(specialty) 커피는 단일종류로 그 섬세한 풍미를 즐기기도 하지만, 대부분의 상업적인 커피 는 가격 경쟁력이 있는 고유한 맛의 제품을 만드는 수단으 로 블렌딩의 과정을 거치게 된다. 최근 타 소재를 블렌딩 함으로써 건강에 유익한 생리활성물질의 함량을 높인 기 능성 블렌딩 커피음료 제조 방법이 보고되고 있으며

*Corresponding author. E-mail : nutrmoon@jnu.ac.kr, Phone : +82-62-530-2141, Fax : +82-62-530-2149

Received 21 February 2020; Revised 09 April 2020; Accepted 13 April 2020.

Copyright (c) The Korean Society of Food Preservation.

This is an Open Access article distributed under the terms of the Creative Commons Attribution Non-Commercial License (http://creativecommons.org/licenses/by-nc/4.0) which permits unrestricted non-commercial use, distribution, and reproduction in any medium, provided the original work is properly cited. 
(Ribeiro 등, 2014), 생두와 볶은 커피를 블렌딩한 커피를 일상적으로 섭취할 경우 혈압과 포도당 및 트리글리세리 드 수치 감소에 긍정적인 영향을 주어 대사증후군 예방효 과가 기대된다는 결과가 보고되기도 하였다(Sarria 등, 2018).

작두콩(Canavalia gladiata)은 아시아 열대지방과 아열 대 지역에서 식용으로 이용되기 시작하였다(Bressani 등, 1987). 동아시아의 많은 지역에서는 한약 소재로도 사용 되고 있으며, 말린 작두콩은 고대 미국 서남부, 멕시코, 중앙아메리카 등에서 식량이나 조림 작물로 사용되기도 하였다(Smartt, 1976). 최근 일본에서는 작두콩 씨앗과 깍 지를 커피 대용차의 원료로 이용하고 있으며, 작두콩의 평균 수확량은 최적의 관리조건에서 대두와 견줄만하며 병충해에도 강하다(Nishizawa 등, 2016). 작두콩의 함유성 분은 일반 콩과 다른 화학적 조성을 지니고 있을 뿐만 아니라, 항산화 활성 또한 매우 높음이 확인된 바 있다(Kim 등, 2013). 즉, 대두나 검정콩 등으로부터는 daidzin, genistin, daidzein 및 genistein과 같은 두류의 대표적인 flavonoid계 함유성분인 isoflavonoid류가 검출되나 작두콩으로부터는 이들 화합물이 검출되지 않았다(Kim 등, 2012). 또한, 작두 콩으로부터 methyl 3,4,5-trihydroxy benzoate(methyl gallate), 3,4,5-trihydroxybenzoic acid(gallic acid), 1,6-di-O-galloyl $\beta$ -D-glucopyranoside, 1,4,6-tri- $O$-galloyl $\beta$-D-glucopyranoside 와 같은 gallic acid 유도체들이 단리 - 동정된 바 있으며, 이들은 동일 농도의 $\alpha$-tocopherol보다 현저히 높은 항산화 활성을 발휘하는 것으로 확인되었다(Kim 등, 2013).

따라서 생리활성이 확인된 천연물 소재인 작두콩을 이 용하여 커피의 맛과 향을 유지하면서 건강 기능성이 증진 된 커피를 개발한다면 커피 애호가들뿐 아니라 카페인 민감성 때문에 커피를 즐겨 마시지 못하는 소비자들에게 도 만족스러운 대안을 제시할 수 있을 것으로 판단하였다. 이에, 본 연구에서는 작두콩 첨가 커피를 제조한 후, 이를 대상으로 총페놀성 화합물의 함량 분석 및 항산화 활성을 평가하였으며, 추가로 작두콩 첨가 커피 투여 쥐 혈장을 대상으로 혈중 과산화물(cholesteryl ester hydroperoxide, $\mathrm{CE}-\mathrm{OOH})$ 생성 억제능을 평가하였다.

\section{재료 및 방법}

\section{재료 및 시약}

본 실험에 사용한 커피생두(Coffea arabica, green bean) 는 2018년에 수확된 브라질 산(Brazil Red Bourbon NY2 Scr. 16 Cerrado Pulped Natural Veloso Estate)을 (주)GSC International(Seoul, Korea)로부터 구입하였다. 작두콩 (Canavalia gladiata, Jacqu. DC)은 2016년에 전남 화순에서 수확한 적색 작두콩(Canavalia gladiata)을 작두콩 생산자
조합(Hwasun, Korea)으로부터 구입하였다.

Acetonitrile $(\mathrm{MeCN})$ 과 methanol $(\mathrm{MeOH})$ 은 HPLC 등급으 로 Fisher Scientific Korea Ltd.(Seoul, Korea)에서 구입하였 으며, acetic acid(AcOH), ascrobic acid, ABTS[2,2'-azinobis(3-ethylbenzothiazoline-6-sulphonic acid)], benzoic acid, BHT(2,6-di-tert-butyl-4-methylphenol), ferulic acid, gallic acid, 1,1-diphenyl-2-picrylhydrazyl(DPPH), 2,6-di-tert-butyl4-methyl-phenol(BHT) 및 trifluoroacetic acid(TFA)는 SigmaAldrich Chemical Co.(St. Louis, MO, USA)로부터 구입하 여 실험에 사용하였다. 그리고 Folin \& Ciocalteu reagent는 Nacalai Tesque(Kyoto, Japan)로부터 구입하여 사용하였다.

\section{작두콩 첨가 커피의 제조}

작두콩은 드럼식 반열풍 로스터(THCR-01, Taehwan Auto. Co., Bucheon, Korea)를 이용하여 $170^{\circ} \mathrm{C}$ 에서 15 분간 로스팅하였다. 볶은 작두콩은 30 분간 끓인 후 충분히 식힌 다음, 정제수를 추가하여 작두콩/물의 비율이 $1: 10(10 \mathrm{~g} /$ $100 \mathrm{~mL}$ )이 되도록 하여 작두콩 추출물을 제조하였다.

커피는 드럼식 반열풍 로스터를 이용하여 커피생두 1.2 $\mathrm{kg}$ 을 $210^{\circ} \mathrm{C}$ 에서 투입한 다음, 12 분 40 초 동안 로스팅 후 $215^{\circ} \mathrm{C}$ 에 배출시켰다. 배전두(roasted bean)는 실온에 24시 간 동안 방치하여 가스 배출(degassing)을 유도한 후, 콜드 브루(cold brew), 에스프레소(espresso), 드립(drip)의 세 가 지 방식으로 각각 커피를 추출하였다(Table 1). 콜드브루 커피는 커피밀(R-220, Fuji royal Co., Tokyo, Japan)을 이용 하여 $0.7 \mathrm{~mm}$ 내외의 입자로 분쇄한 후, cold water drip dutch coffee maker(DC1, Comac Co., Seoul, Korea)를 이용 하여 커피분말의 10 배 $(10 \mathrm{~g} / 100 \mathrm{~mL})$ 에 해당하는 커피 원 액을 추출하였다. 관능평가용 커피 추출액은 밀폐 병에 담아 냉장 보관하면서 사용하였고, 기기분석용 커피 추출 액은 원심분리 $\left(5,000 \mathrm{rpm}, 4^{\circ} \mathrm{C}, 10 \mathrm{~min}\right)$ 와 진공여과(No.2 Whatman, Maidstone, England) 과정을 거친 후 $-70^{\circ} \mathrm{C}$ 에 보관하면서 실험에 사용하였다(Table 1). 에스프레소 커피 는 업소용 커피 그라인더(Super Jolly, Mazzer, Venezia, Italy)를 이용하여 $0.3 \mathrm{~mm}$ 이하의 입자로 분쇄한 후 에스프 레소 머신(Apia II, Nuova simonelli, Chienti, Italy)으로 추출 하였다. 에스프레소 커피는 $10 \mathrm{~g}$ 의 커피분말을 $90 \pm 5^{\circ} \mathrm{C}$ 의 물로 9 기압의 압력을 가해 30 초 이내에 $30 \mathrm{~mL}$ 가 되도록 추출하는 일반적인 방법에 따라 제조하였다(Illy 등, 2002). 이렇게 제조된 에스프레소는 커피분말/추출물의 비율이 $1: 10(10 \mathrm{~g} / 100 \mathrm{~mL})$ 이 되도록 정제수와 혼합한 후 실험에 사용하였다(Table 1). 드립커피는 커피밀로 커피 원두를 0.7 $\mathrm{mm}$ 내외의 입자로 분쇄한 다음, 전기 커피 메이커(Brew station 48465, Hamilton beach, USA)를 이용하여 커피분말 10 배 $(10 \mathrm{~g} / 100 \mathrm{~mL})$ 에 해당하는 커피 원액을 추출하였다 (Table 1). 
Table 1. Condition for extraction method

\begin{tabular}{cccc}
\hline Condition & Cold brew coffee & Espresso coffee & Drip coffee \\
\hline Extractor & $\begin{array}{c}\text { Dutch coffee maker } \\
\text { (Comac) }\end{array}$ & $\begin{array}{c}\text { Simonelle apia2 } \\
\text { (Nuova simonelli) }\end{array}$ & $\begin{array}{c}\text { Brew station } \\
\text { (Hamilton beach) }\end{array}$ \\
Particle size & Fine $(0.5 \mathrm{~mm})$ & Super fine $(0.3 \mathrm{~mm})$ & Medium $(0.7 \mathrm{~mm})$ \\
Water temperature & $20 \pm 5^{\circ} \mathrm{C}$ & $90 \pm 5^{\circ} \mathrm{C}$ & $80 \pm 10^{\circ} \mathrm{C}$ \\
Extraction time & $4 \mathrm{~h}$ & $30 \mathrm{sec} \mathrm{min}$ & $100 \mathrm{~g} / 1 \mathrm{~L}$ \\
Dosage & $100 \mathrm{~g} / 1 \mathrm{~L}$ & $10 \mathrm{~g} / 30 \mathrm{~mL}$ & $100 \mathrm{~g} / 2.5 \mathrm{~L}$ \\
Dilution & $100 \mathrm{~g} / 2.5 \mathrm{~L}$ & $10 \mathrm{~g} / 250 \mathrm{~mL}$ & Coffee $/ \mathrm{water}=1: 2.5(\mathrm{w} / \mathrm{v})$ \\
\end{tabular}

작두콩 첨가 커피는 Lee 등(2007)의 에스프레소 희석 배수별 관능평가 결과를 참고하여 최종 농도에서 커피분 말/물의 비율이 $1: 2.5(\mathrm{w} / \mathrm{v})$ 가 되도록 커피 추출물에 정제수 와 작두콩 추출물을 농도별로 혼합하여 제조하였다. 즉, 무첨가 커피는 커피 추출물 $100 \mathrm{~mL}$ 에 정제수 $150 \mathrm{~mL}$ 를 첨가하여 제조하였으며, 작두콩 $10 \%$ 첨가 커피는 커피 추출물 $100 \mathrm{~mL}$ 에 작두콩 추출물 $25 \mathrm{~mL}$ 와 정제수 $125 \mathrm{~mL}$, 작두콩 $20 \%$ 첨가 커피는 커피 추출물 $100 \mathrm{~mL}$ 에 작두콩 추출물 $50 \mathrm{~mL}$ 와 정제수 $100 \mathrm{~mL}$, 작두콩 $30 \%$ 첨가 커피는 커피 추출물 $100 \mathrm{~mL}$ 에 작두콩 추출물 $75 \mathrm{~mL}$ 와 정제수 $75 \mathrm{~mL}$, 작두콩 $50 \%$ 첨가 커피는 커피 추출물 $100 \mathrm{~mL}$ 에 작두콩 추출물 $125 \mathrm{~mL}$ 와 정제수 $25 \mathrm{~mL}$ 를 혼합함으로써 제조하였다.

\section{총페놀성 화합물의 함량 분석}

총페놀성 화합물의 함량은 Folin \& Ciocalteu's 방법 (Singleton 등, 1965)에 따라 분석하였다. 즉, 커피에 작두콩 첨가량 $(0,10-50 \%)$ 을 달리한 시료 추출물 $1 \mathrm{~mL}$ 를 각각 시험관에 취하고, 여기에 Folin \& Ciocalteu's phenol 시약 $1 \mathrm{~mL}$ 를 가하여 혼합하였다. 이 혼합물에 $\mathrm{Na}_{2} \mathrm{CO}_{3}$ 포화수용 액 $1 \mathrm{~mL}$ 를 더하여 가볍게 혼합한 후, 암실에 30 분간 방치한 다음, UV-VIS spectrophotometer(UVmini-1240, Shimadzu, Kyoto, Japan)로 $700 \mathrm{~nm}$ 에서 흡광도를 측정하였다. 총페놀 성 화합물의 함량은 gallic acid를 이용한 standard curve로 부터 계산하였으며, 이를 gallic acid equivalent(mg GAE/g) 로 제시하였다.

\section{DPPH radical-scavenging 활성 평가}

DPPH radical-scavenging 활성은 Choi 등(1993)의 방법 을 응용하여 평가하였다. 즉, 커피에 작두콩 첨가량 $(0,10$ - $50 \%$ )을 달리한 시료 추출물 $100 \mu \mathrm{L}$ 에 $900 \mu \mathrm{L}$ 의 $\mathrm{MeOH}$ 을 각각 가하여 10 배 희석한 다음, 동량의 $500 \mu \mathrm{M} \mathrm{DPPH}$ (final concentration $250 \mu \mathrm{M}$ ) 용액과 혼합하여 암소에서
30 분간 반응시켰다. 반응액의 흡광도 $(\mathrm{RS})$ 는 $517 \mathrm{~nm}$ 에서 UV-VIS spectrophotometer(UVmini-1240, Shimadzu)를 이용 하여 측정하였다. 대조구로는 ascrobic acid를 사용하였으며, $\mathrm{DPPH}$ radical-scavenging 활성의 정도는 다음과 같이 계산 하였다.

DPPH radical-scavenging activity (\%)

$$
=[(\text { Control }- \text { RS }) / \text { Control }] \times 100
$$

\section{환원력 평가}

각 시료의 환원력은 Oyaizu 등(1986)의 방법을 약간 변 형하여 평가하였다. 즉, 커피에 작두콩 첨가량 $(0,10$ $50 \%$ )을 달리한 시료 추출물 $100 \mathrm{~mL}$ 에 $80 \% \mathrm{EtOH} 500 \mu \mathrm{L}$, $0.2 \mathrm{M}$ phosphate buffer(pH 6.6) $500 \mu \mathrm{L}$ 및 $1 \%$ potassium ferrycyanide $500 \mu \mathrm{L}$ 를 순차적으로 첨가하여 혼합하였다. 혼합용액을 $50^{\circ} \mathrm{C}$ 에서 20 분간 반응시킨 다음, $10 \%$ trichloroacetic acid 용액 $500 \mu \mathrm{L}$ 를 가한 후, 원심분리 $(10,000$ $\mathrm{rpm}, 5 \mathrm{~min}$ )하였다. 원심분리 후에 얻어진 상층액 $750 \mu \mathrm{L}$ 에 $\mathrm{H}_{2} \mathrm{O} 750 \mu \mathrm{L}, 0.1 \% \mathrm{FeCl}_{3}$ 수용액 $100 \mu \mathrm{L}$ 를 혼합하여 10 분 동안 방치한 다음, UV-VIS spectrophotometer(UVmini1240 , Shimadzu)를 이용하여 $700 \mathrm{~nm}$ 에서 흡광도 값을 측 정하였다. 대조구로는 ferulic acid를 사용하였으며, 환원 력은 ferulic acid equivalent $(\mu \mathrm{g} \mathrm{FE} / 100 \mathrm{~mL})$ 로 제시하였다.

\section{$\mathrm{ABTS}^{+}$radical-scavenging 활성 평가}

Stephanie 등의 방법(Dudonne 등, 2009)에 의해 각 시료 의 $\mathrm{ABTS}^{+}$radical-scavenging 활성을 평가하였다. 즉, $7 \mathrm{mM}$ $\mathrm{ABTS}^{+}$radical 수용액과 $2.5 \mathrm{mM}$ potassium persulfate 수용 액을 $95: 5(\mathrm{v} / \mathrm{v})$ 비율로 혼합하고, 암소에서 12시간 동안 반응시킨 후, $735 \mathrm{~nm}$ 에서 흡광도 값이 $0.7 \pm 0.15$ 가 되도록 $\mathrm{EtOH}$ 로 희석하여 $\mathrm{ABTS}^{+}$radical 용액으로 사용하였다. 커 피에 작두콩 첨가량 $(0,10-50 \%)$ 을 달리한 시료 추출물에 $80 \% \mathrm{EtOH} 100 \mu \mathrm{L}$ 를 각각 가한 후, 희석된 $\mathrm{ABTS}^{+}$radical 
용액 $100 \mu \mathrm{L}$ 를 혼합하여 30 분 동안 암소에서 반응시킨 다음, UV-VIS spectrophotometer(UVmini-1240, Shimadzu) 를 이용하여 $517 \mathrm{~nm}$ 에서 흡광도 값(RS)을 측정하였다. 대조구로 $\alpha$-tocopherol을 사용하였으며, 다음과 같은 방법 으로 $\mathrm{ABTS}^{+}$radical-scavenging 활성을 계산하였다.

$\mathrm{ABTS}^{+}$radical-scavenging activity (\%)

$$
=[(\text { Control }-\mathrm{RS}) / \text { Control }] \times 100
$$

\section{Hydroxyl radical-scavenging 활성 평가}

Hydroxyl radical-scavenging 활성 평가는 Xiao 등(2015) 의 방법을 이용하였다. 즉, $400 \mu \mathrm{L}$ 의 $\mathrm{FeSO}_{4} 1 \mathrm{mM}$ 과 400 $\mu \mathrm{L}$ 의 phenanthroline $1 \mathrm{mM}$ 을 가한 후, $0.01 \% \mathrm{H}_{2} \mathrm{O}_{2}$ 를 가하 여 hydroxyl radical의 생성을 유도하였다. 여기에 커피와 작두콩 혼합 추출물 용액 $100 \mu \mathrm{L}$ 를 각각 첨가하여 $37^{\circ} \mathrm{C}$ 에 서 20 분 동안 반응시켰다. 이렇게 얻어진 반응용액을 UV-VIS spectrophotometer(UVmini-1240, Shimadzu)를 이용 하여 $536 \mathrm{~nm}$ 에서 흡광도를 측정하였다. 대조구는 quercetin 을 사용하였으며, hydroxyl radical-scavenging 활성은 아래 의 계산식을 이용하였다.

Hydroxyl radical-scavenging activity (\%)

$$
=\left[(\mathrm{RS}-\text { Control }) /\left(\mathrm{A}_{0}-\text { Control }\right)\right] \times 100
$$

$\mathrm{RS}$ : 시료를 첨가하여 반응시킨 용액의 흡광도

$\mathrm{A}_{0}$ : 시료 및 $\mathrm{H}_{2} \mathrm{O}_{2}$ 를 첨가하지 않은 대조군의 흡광도 Control: 시료를 첨가하지 않은 대조군의 흡광도

\section{쥐 혈장의 cholesteryl ester hydroperoxide(CE- $\mathrm{OOH}$ ) 생성 억제능 평가}

쥐 혈장의 산화 억제능 평가는 Kim 등(2010)의 방법에 따라 행하였다. 즉, 커피에 작두콩 첨가량 $(0,10-50 \%)$ 을 달리한 각각의 작두콩 첨가 커피를 농축한 다음, 얻어진 농축물을 $20 \%$ propylene glycol $1 \mathrm{~mL}$ 에 용해시킨 뒤, Sprague-Dawley계 6주령 수컷(200 g, Samtako bio Korea, Osan, Korea)에 경구투여하고, 경구투여 2시간 후에 대동 맥으로부터 채혈하여 혈장을 분리하였다. 쥐 혈장 $300 \mu \mathrm{L}$ 에 PBS buffer(pH 7.4) 및 동이온 $\left(\mathrm{CuSO}_{4}\right.$, final conc. 100 $\mu \mathrm{M})$ 을 순차적으로 첨가한 후, $37^{\circ} \mathrm{C}$ 에서 8 시간 동안 반응 시켰다. 얻어진 반응액 $100 \mu \mathrm{L}$ 를 취하여 $2.5 \mathrm{mM} \mathrm{BHT}$ $\mathrm{MeOH}$ 용액 $2 \mathrm{~mL}$ 와 $n$-hexane $2 \mathrm{~mL}$ 를 각각 첨가 후 혼합하 였다. 방치 후 분리된 상층액( $n$-hexane 층)을 취하였으며, 동일한 방법으로 재차 상층액을 한 번 더 취해 전 단계의 상층액과 합하여 농축하였다. 얻어진 농축물을 $\mathrm{MeOH} /$ $\mathrm{CHCl}_{3}(95: 5, \mathrm{v} / \mathrm{v})$ 용액 $100 \mu \mathrm{L}$ 로 녹여 다음과 같은 $\mathrm{HPLC}$ 조건으로 시료 중의 $\mathrm{CE}-\mathrm{OOH}$ 농도를 분석하였다. HPLC
분석을 위한 컬럼은 Octyl- $80 \mathrm{Ts}(4.6 \times 150 \mathrm{~mm}, 5 \mu \mathrm{m}$, TSK-gel, Tosoh, Tokyo, Japan)을 사용하였고, 실온에서 유 속은 $1.0 \mathrm{~mL} / \mathrm{min}$ 이었으며, 이동상으로는 $97 \% \mathrm{MeOH}$ 을 사용하여 $280 \mathrm{~nm}(\mathrm{SPD}-10 \mathrm{~A}$ VP, Shimadzu, Kyoto, Japan)에 서 검출하였다. 실험에 사용한 $\mathrm{CE}-\mathrm{OOH}$ 는 본 연구실의 선행연구(Kim 등, 2014)에 의해 합성된 합성품을 이용하 였고, 그 함량 $(\mathrm{mM})$ 은 작성된 $\mathrm{CE}-\mathrm{OOH}$ 표준곡선에 의해 계산하였다. 본 연구에서 행한 동물실험은 전남대학교 동 물실험윤리위원회의 승인(CNU IACUC-YB-2019-38)을 받아 동물실험 지침에 따라 실시하였다.

\section{통계처리}

실험결과는 3 회 반복 측정하여 평균 \pm 표준편차로 나타 내었다. 각 추출물의 항산화 활성 결과에 대한 유의성은 IBM SPSS Statistics 20(IBM Corp., Armonk, NY, USA)을 사용하여 Student's t-test와 Duncan's multiple range test로 평균을 비교하여 나타내었고, $\mathrm{p}<0.05$ 수준에서 통계적 유 의성을 검정하였다.

\section{결과 및 고찰}

\section{작두콩 첨가 커피의 총페놀성 화합물 함량}

작두콩 첨가량을 달리한 커피의 총페놀성 화합물의 함 량 변화를 분석하였다. 콜드브루, 에스프레소 및 드립 방 법으로 추출한 커피 각각에 작두콩 추출물을 농도별로 혼합하여 분석한 결과, 작두콩 무첨가군 $(214 \mathrm{mg} \mathrm{GAE} / \mathrm{g})$ 에 비해 작두콩 첨가군(작두콩 $30 \%$ 첨가군, $251 \mathrm{mg} \mathrm{GAE} / \mathrm{g}$ ) 에서 총페놀성 화합물의 함량이 증가하였으며, 모든 작두 콩 첨가군에 있어 작두콩 첨가량에 따라 농도 의존적으로 커피의 총페놀성 화합물의 함량이 증가하는 현상이 관찰 되었다(Fig. 1). 이는 작두콩에 페놀성 화합물의 함량이 높기 때문으로 판단된다. 콜드브루와 드립 방식으로 조제 한 시료의 총페놀성 화합물 함량은 유의차가 관찰되지 않았으나, 에스프레소 방식에 의해 조제된 시료의 경우, 작두콩을 첨가한 모든 군에서 콜드브루와 드립방식에 비 해 총페놀성 화합물의 함량이 유의적으로 높게 관찰되었 다 $(\mathrm{p}<0.05)$. 이는 에스프레소 추출방식이 드립이나 콜드브 루 추출방식에 비해 강한 압력과 높은 온도를 사용하고, 종이필터 대신 스텐레스 필터를 사용하여 추출효율이 높 아졌기 때문일 것으로 추측된다. 그리고 커피에 작두콩 추출물의 혼합비율을 $50 \%$ 가 되도록 설정한 실험군에 있 어서는 부재료의 첨가 비율이 커피보다 많아 블렌딩의 주체가 달라지는 경향이 있으나, 이는 작두콩 첨가량의 농도의존성에 관한 경향을 평가하기 위함이었다. 즉, 커피 에 작두콩 추출물의 혼합비율이 $50 \%$ 인 경우에도 총페놀 성 화합물의 함량이 증가한 것은 블렌딩 커피의 총페놀성 


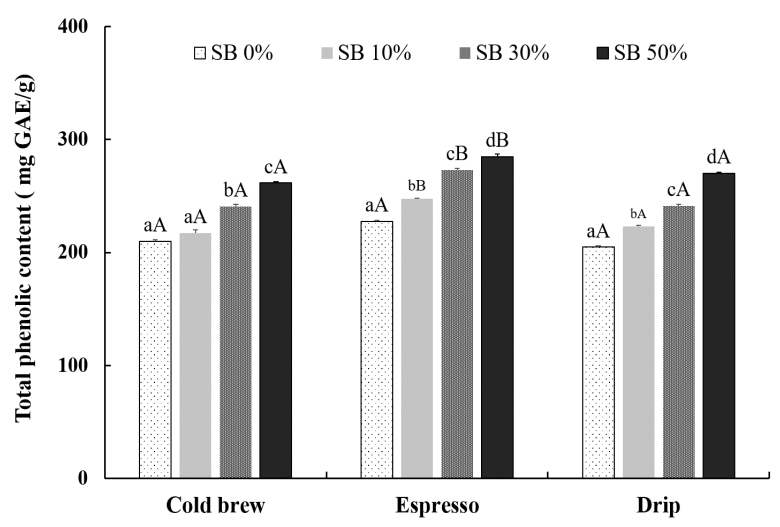

Fig. 1. The content of total phenolics according to different addition rates of sword bean and extraction method.

Values are mean $\pm S D(n=5)$ of triplicate experiments.

${ }^{\text {a-d }}$ Different letters in the same extraction coffee mean significant differences at $\mathrm{p}<0.05$ by Duncan's multiple range test.

${ }^{A-C}$ Different letters in the same concentration of different extraction coffees mean significant differences at $\mathrm{p}<0.05$ by Duncan's multiple range test.

화합물의 함량 증가는 작두콩 추출물의 첨가 농도에 의존 적이었음을 의미한다. 이와 같은 경향은 이하의 항산화능 평가 항목에 있어서도 동일하게 해석될 수 있을 것이다.

\section{DPPH radical-scavenging 활성}

추출방법을 달리한 커피와 작두콩 추출물의 혼합에 의 한 DPPH radical-scavenging 활성을 비교하였다. 콜드브루, 에스프레소 및 드립커피 모두 작두콩 첨가량의 농도에 의존적으로 커피의 DPPH radical-scavenging 활성이 향상 되었다(Fig. 2). 농도별 평균값을 비교해 보면 작두콩 무첨 가군의 활성도가 $19 \%$ 였으며, $20 \%$ 첨가군의 활성도가 $38 \%, 50 \%$ 첨가군의 활성도가 $57 \%$ 로 유의적인 농도의존 성을 보였다( $<<0.05)$. 추출방식에 있어서는 모든 농도에서 콜드브루 < 드립 < 에스프레소의 순으로 항산화 활성이 높게 나타났다. 이러한 결과는 추출방식에 따른 항산화 성분의 차이를 연구한 Budryn 등(2009)과 필터커피와 에 스프레소 커피의 항산화 활성을 비교한 Ludwig 등(2012) 의 연구 결과와도 일치한다.

\section{환원력}

환원력은 $\mathrm{Fe}^{3+}$ 이 추출물 및 항산화 화합물에 의해 $\mathrm{Fe}^{2+}$ 으로 환원되면서 나타나는 흡광도의 차이를 이용하여 평 가하였다. 환원력에 있어서도 앞선 항산화 활성 평가의 결과들과 같은 경향을 보였다. 즉, 작두콩 첨가 농도별로 평균값(ferulic acid 상당량, $\mu \mathrm{g} / \mathrm{coffee} 100 \mathrm{~mL}$ )이 무첨가군 (533)에 비해 $30 \%(1,225)$ 와 $50 \%(1,548)$ 첨가군에 있어 유 의하게 농도 의존적으로 환원력이 향상되었다 $(\mathrm{p}<0.05)$. 또

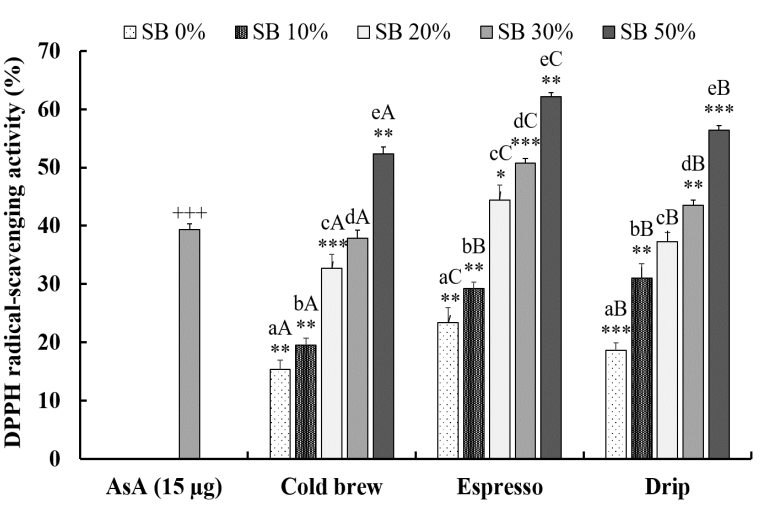

Fig. 2. DPPH radical-scavenging activity according to different addition rates of sword bean and extraction method.

Values are mean $\pm \mathrm{SD}(\mathrm{n}=3)$ of triplicate experiments. Values are mean $\pm \mathrm{SD}(\mathrm{n}=5)$ of triplicate experiments.

${ }^{a-e}$ Different letters in the same extraction coffee mean significant differences at $\mathrm{p}<0.05$ by Duncan's multiple range test.

${ }^{A-C}$ Different letters in the same concentration of different extraction coffees mean significant differences at $\mathrm{p}<0.05$ by Duncan's multiple range test.

${ }^{*} \mathrm{p}<0.05,{ }^{* *} \mathrm{p}<0.01$, and ${ }^{* * *} \mathrm{p}<0.001$ were correlated with the ascorbic acid (AsA) $15 \mu \mathrm{g}$ using the Student's t-test.

한 추출방식에 있어서도 DPPH radical-scavenging 활성과 같은 경향으로 에스프레소 방식에 의해 조제된 커피의 환원력이 타 추출방법에 의해 조제된 커피에 비해 유의적 으로 높은 환원력을 나타났다(Fig. 3).

\section{$\mathrm{ABTS}^{+}$radical-scavenging 활성}

$\mathrm{ABTS}^{+}$radical을 이용하여 추가적인 항산화 활성 평가 를 행하였다. $\mathrm{ABTS}^{+}$radical-scavenging 활성 평가 결과,

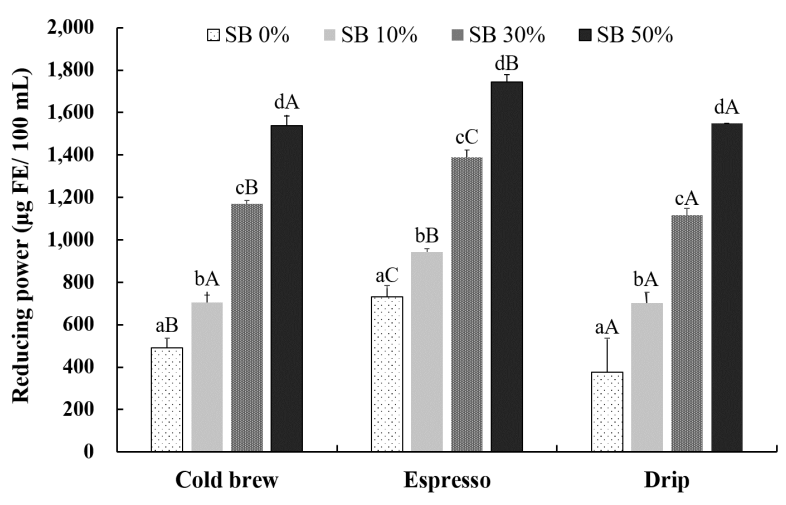

Fig. 3. Reducing power according to different addition rates of sword bean and extraction method.

Values are mean $\pm \mathrm{SD}(\mathrm{n}=5)$ of triplicate experiments.

${ }^{a-d}$ Different letters in the same extraction coffee mean significant differences at $\mathrm{p}<0.05$ by Duncan's multiple range test.

${ }^{A-C}$ Different letters in the same concentration of different extraction coffees mean significant differences at $\mathrm{p}<0.05$ by Duncan's multiple range test. 
콜드브루와 에스프레소에 $30 \%$ 의 작두콩을 첨가했을 때 ascorbic acid $5 \mu \mathrm{g}$ 상당량과 동일한 항산화 활성을 보였다. 추출방식에 있어서는 모든 농도에서 콜드브루 < 드립 < 에스프레소의 순으로 $\mathrm{ABTS}^{+}$radical-scavenging 활성이 $\mathrm{p}<0.05$ 수준에서 높게 나타났다(Fig. 4). 작두콩 첨가 농도 별로는 세가지 추출방식에서 모두 확연한 농도의존성을 보였다. 즉, 무첨가군이 $13 \%, 30 \%$ 첨가군이 $28 \%$, 그리고 $50 \%$ 첨가군이 $38 \%$ 로 활성이 유의하게 향상되었으며, 세 가지 추출방식의 커피 추출물 모두에서 작두콩 첨가에 의해 유사한 경향으로 항산화 활성이 향상됨을 확인할 수 있었다.

\section{Hydroxyl radical-scavenging 활성}

본 실험에서는 Fenton 반응에 의해 $\mathrm{HOOH}$ 로부터 생성 된 hydroxyl radical $(\cdot \mathrm{OH})$ 의 scavenging 정도를 비색법을 이용하여 평가하였다. 이러한 원리를 이용하여 콜드브루, 에스프레소 및 드립의 방법으로 추출한 각각의 커피에 작두콩 추출물을 농도별로 첨가하여 활성을 평가하였다. 그 결과, 콜드브루 작두콩 무첨가 커피의 hydroxyl radicalscavenging 활성은 $5 \%$ 였으나, 작두콩 $30 \%$ 첨가 콜드브루 커피에서는 $20 \%$ 로 증가하였으며, 콜드브루, 에스프레소, 드립 커피 모두에서 농도 의존적으로 활성이 증가하였다 (Fig. 5). 그러나 작두콩 추출물 첨가 커피에 대한 총페놀성 화합물의 함량 및 추출방법에 따른 항산화 활성 비교에 있어서는 전반적으로 에스프레소 추출법이 다른 추출 방 법보다 우수한 경향을 보였다. 반면 hydroxyl radical-

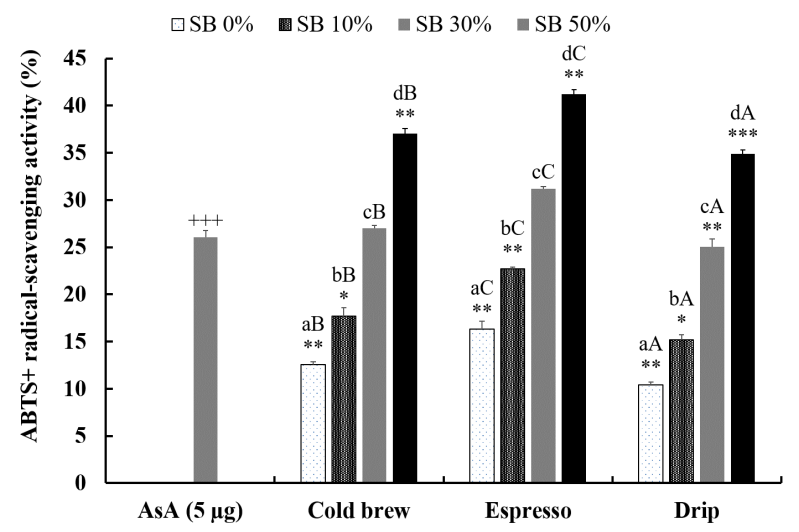

Fig. 4. $\mathrm{ABTS}^{+}$radical-scavenging activity according to different addition rates of sword bean and extraction method.

Values are mean $\pm \mathrm{SD}(\mathrm{n}=5)$ of triplicate experiments.

${ }^{\mathrm{a}-\mathrm{d}}$ Different letters in the same extraction coffee mean significant differences at $\mathrm{p}<0.05$ by Duncan's multiple range test.

${ }^{A-C}$ Different letters in the same concentration of different extraction coffees mean significant differences at $\mathrm{p}<0.05$ by Duncan's multiple range test.

${ }^{*} \mathrm{p}<0.05,{ }^{* *} \mathrm{p}<0.01$, and ${ }^{* * *} \mathrm{p}<0.001$ were correlated with the ascorbic acid (AsA) $15 \mu \mathrm{g}$ using the Student's t-test.

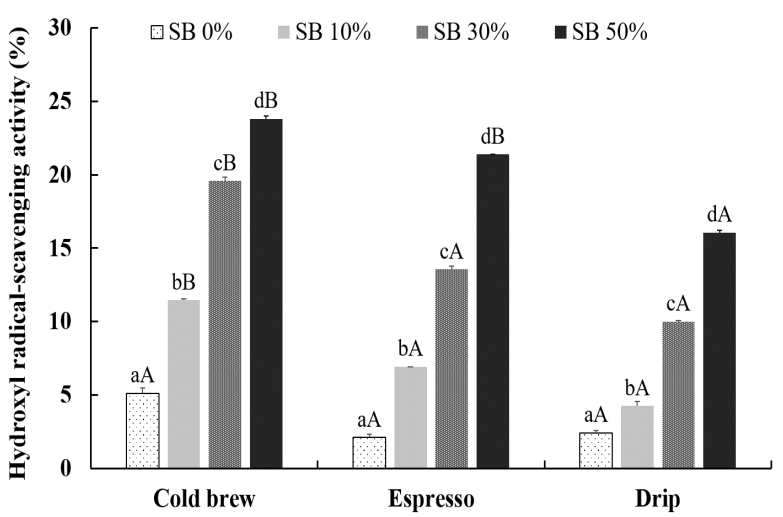

Fig. 5. Hydroxyl radical-scavenging activity according to different addition rates of sword bean and extraction method.

Values are mean $\pm S D(n=5)$ of triplicate experiments.

${ }^{\mathrm{a}-\mathrm{d}}$ Different letters in the same extraction coffee mean significant differences at $\mathrm{p}<0.05$ by Duncan's multiple range test.

${ }^{A-C}$ Different letters in the same concentration of different extraction coffees mean significant differences at $\mathrm{p}<0.05$ by Duncan's multiple range test.

scavenging의 활성에 있어서는 작두콩의 첨가량에 무관하 게 콜드브루 추출법이 에스프레소 추출법보다 더 높은 활성을 보였다. 이는 hydroxyl radical-scavenging능이 우수 한 화합물이 열수 추출시에 일부 소실 또는 감소되기 때문 일 것으로 추측된다.

\section{쥐 혈장의 $\mathrm{CE}-\mathrm{OOH}$ 생성 억제능}

작두콩 첨가 커피 한 잔에 해당하는 양의 농축물을 Sprague-Dawley계 6주령 숫컷 쥐에 경구투여한 후, 2시간 후에 대동맥으로부터 채혈하여 혈장을 분리해 동이온에 의해 유도된 쥐 혈장의 $\mathrm{CE}-\mathrm{OOH}$ 생성 억제능을 평가하였 다. Cholesteryl ester는 혈액 중에 존재하는 물질로서 산소 에 의해 산화되어 $\mathrm{CE}-\mathrm{OOH}$ 를 생성하게 된다. 이는 혈액의 산화정도 지표 화합물들 중의 하나로써 그 생성농도의 비교를 통해 혈장 산화 억제능을 평가하였다. 작두콩 커피 투여 쥐 혈장의 $\mathrm{CE}-\mathrm{OOH}$ 생성 억제능을 평가한 결과, 대조 구에 비해 작두콩 커피 투여군의 $\mathrm{CE}-\mathrm{OOH}$ 생성 억제능에 는 유의차가 관찰되지 않았으나, 대조구의 $\mathrm{CE}-\mathrm{OOH}$ 생성 농도 $(5.2 \mathrm{mM})$ 에 비해 작두콩 무첨가 커피군 $(4.6 \mathrm{mM})$ 과 작두콩 첨가 커피군(4.7-4.8 mM) 모두에서 유의차는 인 정되지 않았으나, $\mathrm{CE}-\mathrm{OOH}$ 의 생성이 억제되는 경향을 보 였다(Fig. 6). 이는 커피 한 잔 분량의 소량만을 쥐에 경구 투여하였음을 고려할 때, 작두콩 첨가 커피의 일상적인 섭취는 혈중 산화 억제효과를 기대할 만하다고 판단된다. 그러나 본 내용은 보다 구체적인 실험군의 설정 및 장기간 의 투여실험 등이 추후 추가될 필요가 있다고 사료된다.

이상 작두콩 추출물을 블렌딩한 커피를 대상으로 항산 화활성을 평가하였다. 그 결과, 작두콩 추출물의 첨가량에 


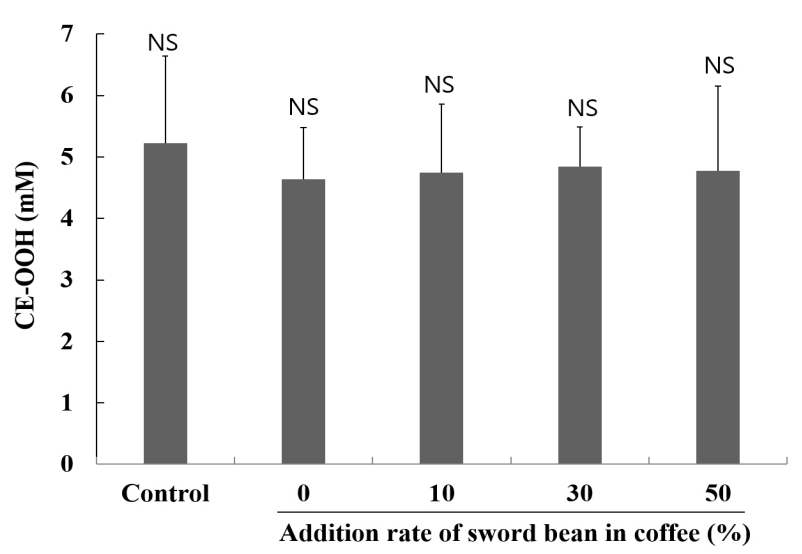

Fig. 6. Inhibition effect of coffee added sword bean against CE-OOH formation in copper ion-induced oxidation of rat plasma.

Values are mean $\pm S D(n=3)$ of triplicate experiments.

NS, no significant difference.

비례하여 항산화 활성이 향상됨이 확인되었다. 이는 작두 콩에 함유된 페놀성 화합물에 의한 영향으로 해석된다. 이에 작두콩은 커피의 항산화능 향상을 위한 블렌딩 소재 로써 응용 가능성이 제시되었다고 판단되며, 커피의 소비 량이 증가하고 있는 최근의 국내 동향을 고려하였을 때, 카페인의 저감화 및 생리활성 향상 측면에 있어 작두콩이 유용한 커피의 블렌딩 소재로 활용될 수 있기를 기대한다.

\section{요 약}

건강 기능성이 강화된 커피음료의 개발을 위해 생리활 성이 우수한 것으로 보고된 작두콩을 부소재로 선발한 후, 커피에 농도별로 첨가하여 커피음료를 제조하고, 항산 화 효과를 평가하였다. 커피 추출방식에 따른 작두콩 첨가 커피를 대상으로 총페놀성 화합물의 함량 분석과 $\mathrm{DPPH}$ radical-scavenging 활성, 환원력, $\mathrm{ABTS}^{+}$radical-scavenging 활성, hydroxyl radical-scavenging 활성 등의 생리활성 평가 를 행한 결과, 모든 항목에서 작두콩 첨가에 따라 농도 의존적으로 활성이 향상됨이 확인되었다. 동물실험을 통 한 cholestery ester hydroperoxide(CE-OOH) 생성 억제능에 있어서도 커피 한 잔 분량의 소량만을 쥐에 경구투여하였 음에도 대조구에 비해 더 높은 $\mathrm{CE}-\mathrm{OOH}$ 생성 억제 경향이 관찰되었다. 따라서, 작두콩 첨가 커피를 일상적으로 섭취 할 경우 커피만을 음용하였을 때보다 카페인 저감효과 및 항산화능의 향상효과를 기대할 수 있을 것으로 판단되 어 작두콩 첨가 커피의 상용화가 기대되는 바이다.

\section{Conflict of interests}

The authors declare no potential conflict of interest.

\section{ORCID}

Hun Cheon Bae https://orcid.org/0000-0003-2662-7082

Jae-Hak Moon https://orcid.org/0000-0002-1927-2124

\section{References}

Bressani R, Brenes RG, Garcia A, Elias, LG. Chemical composition, amino acid content and protein quality of Canavalia spp. seeds. J Sci Food Agri, 40, 17-23 (1987)

Budryn G, Nebesny E, Podsedek A, Zyzelewicz D, Materska M, Jankowski S, Janda B. Effect of different extraction methods on the recovery of chlorogenic acids, caffeine and Maillard reaction products in coffee beans. Eur Food Res Technol, 228, 913-922 (2009)

Choi JS, Lee JH, Park HJ, Kim HG, Young HS, Mun SI. Screening for antioxidant activity of plants and marine algae and its active principles from Prunus daviana. Korean J Pharmacogn, 24, 299-303 (1993)

Davis AP, Govaerts R, Bridson DM, Stoffelen P. An annotated taxonomic conspectus of the genus Coffea (Rubiaceae). Bot J Linn Soc, 152, 465-512 (2006)

Dudonne S, Virtrac X, Coutiere P, Woillez M, Merillon JM. Comparative study of antioxidant properties and total phenolic content of 30 plant extracts of industrial interest using DPPH, ABTS, FRAP, SOD and ORAC assays. J Agric Food Chem, 57, 1768-1774 (2009)

Illy E. The complexity of coffee. Sci Am, 286, 86-91 (2002) Kim JP, Lee HH, Moon JH, Ha DR, Kim ES, Kim JH, Seo $\mathrm{KW}$. Isolation and identification of antioxidants from methanol extract of sword bean (Canavalia gladiata). Korean J Food Sci Technol, 45, 777-784 (2013)

Kim JP, Yang YS, Kim JH, Lee HH, Kim ES, Moon YW, Kim JY, Chung JK. Chemical properties and DPPH radical scavenging ability of sword bean (Canavalia gladiata) extract. Korean J Food Sci Technol, 44, 441446 (2012)

Kim JY, Cho JY, Ma YK, Lee YG, Moon JH. Nonallergenic urushiol derivatives inhibit the oxidation of unilamellar vesicles and of rat plasma induced by various radical generators. Free Radical Biol Med, 71, 379-389 (2014)

Kim KD, Lee YS, Cho JY, Lee YH, Choi KJ, Lee Y, Han TH, Lee SH, Park KH, Moon JH. Comparison of the content of bioactive substances and the inhibitory effects against rat plasma oxidation of conventional and organic hot peppers (Capsicum annuum L.). J Agric Food Chem, 
58, 12300-12306 (2010)

Lashermes P, Combes MC, Robert J, Trouslot P, D'Hont A, Anthony F, Charrier A. Molecular characterisation and origin of the Coffea arabica L. genome. Mol Gen Genet, 261, 259-266 (1999)

Lee SY, Hwang IK, Park MH, Seo HS. Sensory characteristics of diluted espresso (americano) in relation to dilution rates. Korean J Food Cookery Sci, 23, 839-847 (2007)

Ludwig IA, Sanchez L, Caemmerer B, Kroh LW, De Pena MP, Cid C. Extraction of coffee antioxidants: Impact of brewing time and method. Food Res Int, 48, 57-64 (2012)

Nishizawa K, Masuda T, Takenaka Y, Masui H, Tani F, Arii Y. Precipitation of sword bean proteins by heating and addition of magnesium chloride in a crude extract. Biosci Biotechnol Biochem, 80, 1623-1631 (2016)

Oyaizu M. Studies on products of browning reactions: Antioxidative activities of products of browning reaction prepared from glucosamine. Jpn J Nutr Diet, 44, 307-315 (1986)

Ribeiro VS, Leitao AE, Ramalho JC, Lidon FC. Chemical characterization and antioxidant properties of a new coffee blend with cocoa, coffee silverskin and green coffee minimally processed. Food Res Int, 61, 39-47 (2014)

Sanz C, Maeztu L, Zapelena MJ, Bello J, Cid C. Profiles of volatile compounds and sensory analysis of three blends of coffee: Influence of different proportions of arabica and robusta and influence of roasting coffee with sugar. J Sci Food Agric, 82, 840-847 (2002)

Sarria B, Martinez-Lopez S, Sierra-Cinos JL, Garcia-Diz L, Mateos R, Bravo-Clemente L. Regularly consuming a green/roasted coffee blend reduces the risk of metabolic syndrome. Eur J Nutr, 57, 269-278 (2018)

Singleton VL, Rossi JA. Colorimetry of total phenolics with phospomolybdic-phosphotungstic acid reagents. Am J Enol Vitic, 16, 144-158 (1965)

Smartt J. Canavalia gladiata (Jacq.) D.C. (sword bean). In: Tropical Pulses, Longman Group Ltd, London, England. p 57-58 (1976)

USDA. Coffee: World Markets and Trade. Foreign Agricultural Service (2017)

Xiao Y, Wang L, Rui X, Li W, Chen X, Jiang M, Dong M. Enhancement of the antioxidant capacity of soy whey by fermentation with Lactobacillus plantarum B1-6. J Funct Foods, 12, 33-44 (2015) 